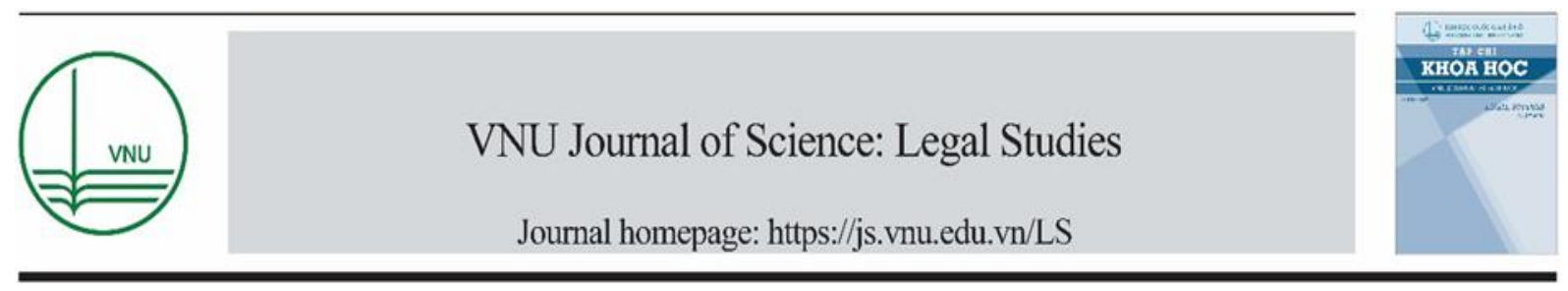

Original Article

\title{
Judicial Interpretation of "Consent" in Rape Cases in Indian Courts and Application in Marital Rape Cases
}

\author{
K. Mayukha Chihnitha* \\ NALSAR University of Law, PO Box No.1, Shamirpet, Hyderabad, Telangana, India \\ Received 02 January 2021 \\ Revised 03 March 2021; Accepted 17 June 2021
}

\begin{abstract}
Indian Judiciary has been defining "consent" according to the changing societal perspectives. The criminal justice system has considered itself liberal while giving such definitions and clarifications on the concept of consent in rape cases. This paper examines the definitions and interpretation of consent in various judgements given by the Indian High Courts and the Supreme Court of India and examines the possibilities of applying the same interpretations to marital rape. This paper also analyses various criticisms that were faced by some of the judgements, which interpreted consent in various ways. From this analysis, I shall try to analyze the reason why Indian justice system (hereinafter mentioned as the justice system) is procrastinating the debate on criminalizing marital rape by using the same rationale of consent, which is applied in rape cases.
\end{abstract}

Keywords: Consent, Judiciary, Rape, Marital Rape, Judgements, Interpretation, India, Indian Courts.

\section{Methodology}

Research question: In this paper, I try to find answer to the question, if the constantly evolving definition of consent in rape can be applied to criminalize marital rape. This analysis also includes the reasons that Indian Judicial system gives for not criminalizing marital rape.

Sources: I studied many articles and research papers by the scholars from various disciplines to obtain as many perspectives of

\footnotetext{
${ }^{*}$ Corresponding author.

E-mail address: mayukha.kmc98@gmail.com https://doi.org/10.25073/2588-1167/vnuls.4342
}

consent as possible. This paper also studies various judgements and obiter dicta on consent. I have gone through some blogs, articles from newspapers and books, which tried to interpret and analyze the application of consent by the Indian justice system in cases of rape.

Scope \& limitations: This paper analyzes the interpretation and application of consent in rape cases. I have obtained some research papers submitted by various scholars to different universities and analyzed them. I have referred many articles online and offline to study these concepts. Most importantly, I have studied many Indian judgements in rape cases. However, I have chosen to mention only a few, 
which are pertinent to answer the research question.

Aims and Objectives: This paper follows the Interpretive Approach that Max Travers talks about in his paper called "Putting Sociology Back into the Sociology of Law" [1].

- To analyze the concept of consent in rape cases given by the Indian judicial precedents.

- Analysis of the perceptions on those precedents by various scholars.

- To analyze the possibility of application of the present and established definition and interpretation of consent in marital rape cases to criminalize marital rape in India.

\section{Introduction}

Section 375 of IPC, criminalizes sexual intercourse with a wife, who is 15 years old and less, by her husband. The Supreme Court of India (SC) in Independent Thought v. Union of India [2], ruled that sex with a wife who is a minor (less than 18 years old) is rape, regardless of consent. However, the rape of a married women who is 18 years old and above, by her husband, is still not considered rape. Since ages, rape is considered as a crime, which is easy to accuse and hard to prove. One of the main reasons of this is that there are often, no witnesses and the court needs to rely on the facts given by both the parties, which are obviously in contrast and the reliance is on other available evidence. Though these are the reasons that are cited by the scholars, the main conception of rape being an 'easily-accused' crime, come from the notion of women being considered inferior individuals who cannot make strong decisions and weak in maintaining "character" - inherently and complicity operating patriarchy is the main cause of such conception. The reason for marital rape not being criminalized, comes from the Victorian norm of consent being given at the time of wedding, which is irrevocable and after wedding, man and his wife become a single entity, which cannot be separated [3]. However, in Indian context, Hindu marriage is considered sacramental and Muslim marriage is considered partially sacramental (presence of process of reciting some verses of Quran) and partially contractual. Most of the times, the Indian Justice system cited the reason of marriage and family system being collapsed in case marital rape is criminalized. Women, basically wives, were treated as property of their husbands and the law was made as such that the men protect their 'property' from other men [4]. All the cases that will be discussed in this paper are selectively picked up after analyzing various judgements and these cases give the idea as to how the courts have interpreted consent using the facts of the respective cases and how those facts changed the interpretation of consent.

\section{Analysis of the Indian Courts' Interpretation of "Consent"}

\subsection{Mahmood Farooqui v. State: [5]}

The Delhi High court, in the case where film director Mahmood Farooqui was accused of rape (oral sex without consent), acquitted him saying that there was no clarity in the case to establish the absence of consent. This was one of the many grounds for the acquittal. The court concluded this because the resistance on part of the victim was 'feeble'. Precisely, the court did not consider a weak 'no' and this raised curtains for the debate whether hesitant denial is sufficient to establish the absence of consent. When the victim challenged this verdict in the Supreme Court, the court held that it is a well-decided case and upheld the acquittal, saying that there are no reasons for the court to believe that the act of oral sex happened with a negated consent. This judgement by Delhi High Court accrued major criticisms because it tried to reinforce the stereotypes like 'No does not all ways mean no' and further stated that there are examples where a feeble 'no' from a woman, in certain circumstances, means a 'yes'.

Another reason why this judgment is criticized because, the court reversed the trial court judgement which held Mr. Farooqui, 
guilty and said that the victim faked an orgasm which makes the rape accusation unreliable. The victim claimed that she had faked an orgasm fearing the violence that had happened in the case of Nirbhaya (in famous rape case with extremely excessive violence), where one of the perpetrators said that had Nirbhaya remained silent and had not resisted, they would not have injured her so badly. The Delhi High Court described this as an 'act of passion' and the circumstances should be considered while trying to establish consent. Section 375 of IPC defines consent to be clear and voluntary. It should be unequivocal, including non-verbal forms of communication [6]. All the criticisms that this judgement has received and is receiving are more sensible than the judgement and its reasoning.

Section 114-A of Evidence Act [7], allows to make a presumption of absence of consent when such accusation is made by the victim. In this case, the court completely ignored the presence of coercive and potentially dangerous circumstances. The definition and concept of consent is almost the same all over the world. The burden to prove is on accused I.e. to establish that the sexual intercourse was consensual. This is also applied almost in all the countries. However, sometimes, these definitions are focused on presence of consent, rather the procedure to obtain such consent. There are countries that recognize the presence of coercive conditions and one of such countries in Namibia.

Deelip Singh v. State of Bihar: [8]

Description of facts of the case is relevant for this paper. In this case, the victim filed an FIR against the alleged perpetrator while she was pregnant by 6 months. According to the victim, she was in love with the alleged perpetrator, who was also her neighbour. She alleged that he raped her and then promised to marry her. She said that because, he promised marriage with her and their physical intimacy continued. The relations and parents of the victim were also aware of their intimacy and they believed that he would marry her eventually. The accused continuously avoided the marriage and father of the victim tried to persuade him, but in vain. Left with no other option, the victim filed an FIR against the accused. During the trial, the majority of the victim was also questioned. Later, it was proved in court of law that the victim was major and her consent matters. Only then, the court proceeded to deal with the further questions. The charges of rape were pressed against the accused on the grounds of 'misconception of fact'. The Apex Court held that intercourse with consent obtained through false promise of marrying the woman, this will be considered rape under misconception of fact. However, the Court held that in this case, it is a "breach of promise" and not a false promise. This is because the prosecutrix was unable to prove the lack of intention to marry her, on part of the victim, beyond reasonable doubt. The Court acquitted the accused from the charges of rape, but held him liable for a breach of promise and ordered him to pay a sum of INR 50,000. This case is highly criticized for the way the Court dealt with consent. The Court relied on establishing the intention to marry or not marry her, on part of the accused. The Court agreed that consent obtained by false promise of marriage shall be vitiated. In the case of Uday v. State of Karnataka, [9] the Court held that under the said circumstance, the consent will not be vitiated and will not be considered rape. The court observed this even when it was established the accused had no intention of marriage. Now, in the present case, the court acknowledged that false promise of marriage would fall under the definition of misconception of fact in the code. In Deelip's case, the court recognized that the consent will be vitiated by false promise, yet acquitted the victim by getting 'intention' into the case. In a similar case, Rani Panda v. State of Bengal [10], the court held that there is lack of evidence to prove the absence of intention. Thus, it amounts to failure to keep up his promise and not a false promise. 


\subsection{Independent Thought v. Union of India:}

The judgement that criminalized the sexual intercourse with wife, who is below 18 years, is mostly based on the POCSO act and its overriding effect, Articles 14, 21 and 15. This judgement is a huge step taken by the court to protect the minor girls from being raped by their husbands. However, the judicial system failed to protect women who are 18 and above 18 years old from such atrocity being committed on them by their husbands. However, this judgement did not consider the cases where the husband is also underage and consensual sexual intercourse happens between them. But this point might start another debate about having gender neutral rape laws in India. The judgement also mentions that the case is not about 'marital rape' as such and only the matter that the bench is dealing. It is not about the girls who are 18 and older. However, the court ignored the fact that the reasoning applied in this case, which is that the exception 2 violates fundamental rights and is applicable to women who are 18 and older, without any limitations.

\subsection{G. Achyut Kumar v. State of Odisha: [11]}

In this latest judgement by Odisha High Court, it was controversially ruled that the intention of lawmakers is that the rape laws should not intervene in personal and consensual relationships and thus ruled that the rape law will not cover the present case because the perpetrator and the victim are in a consensual relationship. The judge also commented 'virginity is a prized element,' which in itself is a very conservative and misogynistic statement. Even if the interpretation of the intention of the lawmakers is considered, it still restricts the justice being denied to the victims who are in a relationship and started the consensual act, which later turned into a non-consensual one. The Judge in this case cited another judgment titled Arak Sk. v. State of West Bengal [12], in which the court held that when the accused abandons a girl on getting pregnant, who he had promised to marry, is wrong but it should not be considered rape.

\subsection{Rao Harnarain Singh v. State of Punjab: [13]}

In this case, the court held that consent is said to be present when the woman has applied her reasonable mind to the circumstances and situations, decides to give her consent for intercourse. The requirement for the consent to be present is that she should have an option to revoke such consent during anytime of the act. The Supreme Court in the case of State of Himachal Pradesh v. Mango Ram [14], ruled that all this should be decided based on all the relevant circumstances of the case.

\subsection{Pratap Misra \& Ors. v. State of Orissa: [15]}

The victim in this case used to be a concubine and was in a bigamous relationship with a married man. She went to a National park with her husband, on a fun trip, while she was 5 month pregnant. There, she was gangraped by three people. Due to this, the woman had to suffer a miscarriage. The court decision in this case is very disturbing. The court ruled that she consented to the intercourse with those three accused and she did not scream but merely 'sobbed' while the act was happening. Thus, it was not rape. The court further said that had the fetus been aborted immediately after the act, then it could have been concluded that the act was done by force. But the miscarriage happened few days subsequent to the act.

\subsection{Tukaram \& Ors. v. State of Maharashtra: [16]}

Infamously known as Mathura rape case, this is one of the most criticized judgements given by an Indian Court. Mathura was a sixteen-year-old tribal girl, who was gang-raped in a police station. The accused were acquitted by the SC because, there were no injuries on Mathura's body and thus it was a 'peaceful' and consensual affair. Her tribe had a practice of open marriage and thus she was labelled a woman with 'immoral character' and thus the court did not 'trust' in her testimony. 


\section{Did the Courts' Perceive the Cases in the Point of View of the Victims or is it Just Patronizing them?}

To understand the explanation of the above analysis, we need to understand the analysis of Srimati Basu in her article titled "Cutting to size".[17] In this paper by Basu, she studies various cases to present a pattern about the way in which judiciary is acting towards the women. She criticizes the elite male people who are in the positions of authority for using the redefinition of women's rights as a weapon to establish command. While she discusses this topic in the context of property law, the gist of the paper can be applied to the cases of rape and the judgements can be analyzed this way. To summarize Basu's argument in a reductionist manner, the court often acts as a savior to the women who fit in the 'stereotypical' victim bracket and rule in their favour while the judges put themselves in a position of authority by treating such judgement as a mere help to the "victim". Such approach can in no way be considered as progressive and the judges are not acting as the allies of equality in anyway.

After analyzing the interpretations and "considerations" that the courts have made and refrained from making for the victims of rape and for the victims of marital rape, respectively, my conscious and reasonability certainly makes me question, if this whole process of "delivering justice" for the victims and "protecting" the potential victims of rape, is a mere act of patronizing women by the whole justice system. This would surely be a strong statement to make. However, I propose that it is very important to try to find an answer for this question or a mere explanation for the acts of justice system. This should not in anyway be considered as an attack or blame on the judiciary. This is just a process of deciphering the results of such interpretations by the judges. Pratap Misra's case is an example of such cases where the court used this 'ideal victim' concept, where, to fit into the box of 'victim', a woman should qualify certain criteria. In this case, the history of the women being concubine, having involved in a bigamous marriage and the fact that she did not scream, are not the situations, which the court expected to be the traits of victim. These affected her case and it was held that the act was consensual. In Mathura rape case, just because the victim was not a virgin, had sexual intercourse several times in her life, she became a liar and her testimony has been rendered untrustworthy.

The problem, with such judgements is that, instead of trying to make society a better or safer place, the system asks the women to be careful and men to be mindful of the fact that they 'might' be adjudicated for their acts. The system waits for months and years to make an affirmative decision, which brings a change in society. The court responds only when some brutal act is committed and someone is indicted. It is merely curative and not preventive. The judiciary waited to address the problem of interpretation of passive consent till the country agitated the decision in Mathura's case. The wait to amend the definition of rape continued till Nirbhaya's case happened.

As India celebrated the hangings of Nirbhaya convicts in March 2020, saying that the justice has been delivered at last, it just shows our obsession with violence and brutality [18]. Nothing has changed drastically even after Nirbhaya and Disha incidents. The encounters of the accused in Disha's case was also widely celebrated by us. Most of us hoped that there would be a drastic decrease in the number of rape cases. Unfortunately, that did not happen. The following day, of Disha's incident, other rape cases were quickly registered in the country. The conviction rate in the cases of rape in India seriously low at $27.2 \%$, according to National Crime Records Bureau (NCRB). The conviction rates dropped to the said percentage from $32.2 \%$ from the previous year.

All these acts by judiciary point that the judgements that were delivered are mere consolations for the victims and not the decisions made to curtail such crimes in future and in some cases, they were mere suitable responses to the agitations by the people of the country. For instance, the Deelip's case is an 
example where the justice system used its interpretation to acquit the accused by saying that the act does not include the failure to keep the promise. This defies the object of the concept of consent and opens it for prospective cases where the defendant would claim that he has always had an intention to marry the victim but he failed to do so because of the 'circumstances'. This is a problematic precedent.

\section{Application of this Definiton in Marital Rape}

The above cases are the evident and famous example of the failure of the Indian judiciary with the steps that are preventive in nature for rape cases. The judiciary might wait till a case of marital rape gets to the bench, which is brutal enough for the society to consider that lack of criminalization of marital rape is problematic and for the protests to happen, to criminalize marital by applying their own definitions and interpretations of consent. Despondently, it would be too late and numerous victims who are silent victims of marital rape would have to watch their perpetrators go unpunished and continue to perpetrate the crime without any legal restrictions.

Another aspect of criminalizing marital rape is considering the brutality of the act. We, as a hypocritical society, would always consider that only those victims who are injured so brutally that our standards of brutality and the characteristics of 'victim' are met, deserve the justice, quickly and the perpetrator should be punished as brutally as possible. Ironically, we forget that our opinions do not matter and the victims need not be injured badly to prove that they have been raped. This is the case with most of the rapes that happen inside marriage. There wouldn't be bad injuries but there is a victim and a perpetrator and yes, RAPE.

Marital rape has this element of inducing serious mental health issues. The victim has to live her life with her rapist as if nothing had happened to her and not being sure if it might happen again. She should give birth to the children who are results of rape. Though marital rape is a ground for divorce and the husband can be tried for raping his wife under domestic violence (marital rape is not a criminal offence under Indian Penal Code), this would not compensate the crime that has been committed. Nothing can compensate a victim of rape. But denying the minimum that the justice system can do, is not a very progressive or even a moral response that should come from the justice system. This might sound emotionally motivated argument and might be criticized on those grounds. However, when something is affecting the victims in an emotional way, then why not consider the emotional arguments? While that is said, the other facts that this paper discusses are not emotional in nature but purely legal. However, the justice system always seem to find one or the other reason to not proceed with criminalizing one of the most brutal form of tortures.

\section{Conclusion}

Applying the interpretive approach, which is coming to a conclusion after studying the patterns and the actors, it can be said that the justice system is walking on egg shells in its interpretation of concept of consent. All the cases and interpretations denote towards the conclusions that the Indian courts mostly presume this 'ideal victim' identity of the victims and the victims who do not fit into the ambit of that idealness are being denied justice in the most blatant to the most subtle forms. The courts seem to adopt this savior complex where they assume the duty towards only those who fit into the bracket of 'helpless ideal victim, who is brutally affected'. The other concerns are being ignored or considered not as pertinent as the stereotypical considerations by the Indian courts of law.

The statements made by former actors of the Indian judicial system indicate that the system is more interested in 'preserving' the family system and marriage system from collapse by saying that criminalizing marital 
rape would lead to the aforementioned incidents. However, the judiciary keeps ignoring the fact that bodily integrity and sexual autonomy, that are part of Fundamental Right to life under Article 21 of Indian Constitution, cannot be compromised. Treating the rape of a minor married/ unmarried woman, different from the rape of a women who is a major and married, cannot be justified by citing reasons involving systems, which are, according to some feminist scholars, are oppressive towards women. Judicial activism is not new to Indian justice system. It is high time that the judges, who are bequeathed with the power and responsibility to protect women from toxic marriages and toxic family systems, should act accordingly and criminalize marital rape. The starting point of this is when these judges get out of the ambit of 'ideal victim' and consider wide range of circumstances in interpreting the concept of consent.

\section{References}

[1] Travers, Max, Putting Sociology Back into the Sociology of Law, Journal of Law and Society, Vol. 20, No. 4 (Winter, 1993).

[2] 2017 SCC Online SC 1222.

[3] H. Clark, Law of Domestic Relation in the United States 219 (1968).

[4] Toner, The Facts of Rape 112-30 (1977).

[5] (2017) 4 DLT (Cri) 328.

[6] Indian Penal Code, s. 375 (1860).

[7] Indian Evidence Act, s. 114-A (1872).

[8] (2005) 1SCC 88.

[9] AIR 2003 SC 1639

[10] 1984 Cri. L.J 1535.

[11] 2020 SCC OnLine Ori 417.

[12] (2001) Cri. L.J. 416 (Calcutta HC).

[13] AIR 1958 P\&H 123.

[14] 2000 Supreme Court Cases (Cri) 1331.

[15] 1977 SCC (Cri) 447.

[16] 1979 Supreme Court Cases (Cri) 381.

[17] Basu, Srimati, Cutting to Size: Property and Gender Identity in the Indian Courts in Rajeshwari Sunder Rajan (ed), (2002), New Delhi: Kali for women.

[18] Nirbhaya Convicts Hanged IN Tihar JaIl The WIRE, https://thewire.in/law/nirbhaya-convictshanged-2 (last visited May 27, 2020). 